Отримано: 9 лютого 2019 p.

Прорецензовано: 25 лютого 2019 р.

Прийнято до друку: 1 березня 2019 р.

e-mail: sve-romanyuk@ukr.net

DOI: $10.25264 / 2519-2558-2019-5(73)-170-172$
Svitlana Romanyuk, Veronika Trofimchuk. Students' self-study in the process of studying foreign language. Наукові записки Начіонального університету «Острозька академія»: серія «Філологія». Острог: Вид-во НаУОА, 2019. Вип. 5(73), березень. C. $170-172$.

\author{
Svitlana Romanyuk, \\ PhD (Candidate of Philological Sciences), Associate Professor \\ Veronika Trofimchuk, \\ Senior Lecturer, Department of Foreign Languages, Rivne State University of the Humanities
}

УДК 378.147

\title{
STUDENTS' SELF-STUDY IN THE PROCESS OF STUDYING FOREIGN LANGUAGE
}

The article deals with the organization of students' self-study, its role and meaning while studying a foreign language in higher educational institutions.

In the article the functions and goals of students 'self-study are considered. The analysis of the forms of students' self-study was conducted. The most effective its types and forms are revealed. In particular, we consider effective methods of carrying out students'self-study, which allow to make the educational process more successful and bring it to a new level.

The project method allows students to acquire information in a foreign language independently from different sources, work with it, make generalizations, draw conclusions and apply the obtained knowledge in practice. Computer technologies stimulate students' interest in learning a foreign language, develop speaking, reading, writing and listening skills. Communicating students online with foreigners turns a foreign language into a real-life communication mean. Work with video materials diversifies student activities, increases the level of motivation for studying a foreign language, makes it possible to work with authentic language samples, which is especially relevant in the absence of a foreign language environment.

Key words: students' self-study, foreign language, forms, methods, efficiency.

\author{
Романюк Світлана Костянтинівна, \\ кандидат філологічних наук, доиент кафедри іноземних мов, Рівненський державний гуманітарний університет, \\ Трофімчук Вероніка Миколаӥвна, \\ старший викладач кафедри іноземних мов, Рівненський державний гуманітарний університет.
}

\section{САМОСТІЙНА РОБОТА СТУДЕНТА У ПРОЦЕСІ ВИВЧЕННЯ ІНОЗЕМНОЇ МОВИ}

Стаття присвячена організації самостійної роботи студентів, ї̈ ролі та значенню під час вивчення іноземної мови у вищих навчальних закладах.

У статті розглянуто функиії та иілі самостійної роботи. Проведено аналіз форм самостійної роботи. Виявлено найбільш ефективні ї̈ види і форми. Зокрема, розглядаються ефективні методи проведення самостійної роботи, які дозволяють зробити навчальний прочес більш успішним і вивести його на новий рівень.

Правильно організована самостійна робота у вищих навчальних закладах сприяє успішному та ефективному оволодінню іноземною мовою, а також забезпечує розвиток творчих здібностей студентів.

Ключові слова: самостійна робота студентів, іноземна мова, форми, методи, ефективність.

Formulation and justification of the relevance of the problem. The relevance of the problem of self-study is increasing due to the need to prepare students for study throughout their lives. At the present stage of accelerated socio-economic development of society, the study of foreign language in higher education institutions becomes of special importance, because its knowledge is an essential factor in the high professional competence of future specialists.

A characteristic feature of the scientific organization of the educational process in higher educational institutions of Ukraine is the gradual increase in the time for independent extra-curriculum work of students, which is an organic continuation of the classroom work, an important source of satisfying cognitive needs, a means of supporting and further developing educational and professional motives for learning a foreign language. To teach students to self-replenish their knowledge, to independently navigate in the rapid flow of new information is an important urgent task of modern high school.

Analysis of recent research and publications. The problem of self-study in higher educational establishments highlighted in studies on pedagogy and psychology (V. Burynskyi, V. Lutsenko, V. Moroz, M. Soldatenko, I. Chomyak, etc.). Many studies of this problem have been conducted in the field of teaching methods of foreign languages (S. Zaskaleta, N. Koriakovtseva, L. Oliinyk, L. Onuchak, Ye. Polat, etc.).

The aim of the study is to consider the specifics and problems of organizing students' self-study of a foreign language and to identify those forms and methods of work that will promote the most complete realization of the goals of teaching.

The main material of the study. The definition of "self-study" suggested by N. Yangelska deserves much attention. According to her definition "self-study" should be understood as a form of organization and implementation of educational and cognitive activities of students, which is directed and supervised by the teacher or the student himself in accordance with the curriculum and the individual needs in classroom classes or outside the classroom in order to acquire professional knowledge, skills and abilities and for self-improvement [9].

Self-study performs two functions:

- advisory, when teacher helps students to master theoretical and practical material in classroom classes and gain useful skills;

- controlling, based on the conducting by teacher current and final controls, checking homework and written students' works.

Self-study outside the classroom should achieve the following goals:

- mastering the fundamental knowledge, skills and abilities; 
- consolidation and systematization of the received knowledge;

- formation of skills and abilities;

- obtaining own experience of creative and research activity.

In the process of students' self-study the ability to realize, define and formulate their cognitive and information needs, information request, the skills of searching, selecting, analyzing, systematizing, and transferring information is formed. Not less important is the habit of constantly working with foreign sources of information and ability to switch attention from language forms to information. One of the main goals of self-study in a foreign language is the formation of cognitive and informational interests not only in connection with specific types of training activities, but as an element of a common culture of personality, as a way of self-improvement [6].

The means of independent work organization can be the following: 1) availability of textbooks and methodical instructions for independent work; 2) availability of educational audio, video and computer training programs; 3) application of the system of communicative tasks for the development of all communicative abilities [4].

It is necessary to take into account that the main factors of mastering and consolidating the educational material of a course are the forms of student's self-study, which depend primarily on the content of the academic discipline, the degree of preparedness and independence of the student, as well as the skills and qualifications of the teacher. Each teacher in conducting classes should have a large variety of tasks and exercises for student's self-study, which should not be limited to simple essays, reports, theses, control tasks.

It is necessary to imagine opportunities of every student, therefore, realizing personally oriented approach in teaching, the teacher must build a modified, adapted individual program for each student, that allows to choose different tempo, ways and stages of work [4].

Traditionally independent work of students is carried out according to the following forms:

- individual (abstract, course paper, diploma paper, independent research work, individual counseling, olympiads, etc.);

- group (project and problem learning, coaching, gaming project, group counseling, optional classes, classes in circles);

- mass (project training, programmed training) [2].

We listed the standard most common forms of students' self-study, not tied to the specifics of a particular discipline.

The goal of this article is to study the most effective forms of students' self-study in learning English, which is used in all areas of international business and law, politics and science in the context of internationalization and globalization of the world economy.

Students' self-study in learning English should be based on the use of active teaching methods, which include essays, projecting, using audio and video materials, Internet sites, working with texts of fiction in English (annotation, reviewing, referencing), working in groups, performing of olympiad tasks and exercises, portfolio, solution of the educational problems, situation playing, monologue on a given topic, staged theatrical tasks in English, participation in student scientific societies, language clubs [1].

In modern pedagogical practice among the most effective methods of students' self-study, which contributing to individualization and intensification of educational process, should be pointed out:

- problem-searching methods;

- method of project training;

- method of using the latest information and communication technologies in studying [3].

Problem-searching methods are aimed at activating the student's cognitive activity. The application of these methods encourages students to conducting independent researches, increases the motivation for further work, promotes the development of logical thinking, as a consequence of the development of their creative independent activities. The ideal result of learnsng with the help of problem-searching methods is the formation of skills to apply rationally all the components of these methods in development and interconnection [5].

Working with authentic or professional literature in foreign languages aims to acquire the skills to obtain the necessary information. Then performing creative tasks that include work with popular scientific texts corresponding to specialty of student, reading, analysis, referencing of scientific articles in order to write an abstract and its presentation at a student's scientific conference and, finally, defense of thesis in a foreign language.

While working with periodicals in foreign languages it is desirable to pay more attention to the short search task: to write a professional vocabulary, analyze the titles of articles, compose a sample ad, draw up an outline of an interested article, write out and analyze promotional slogans and create your own.

The Internet is a great way to get information about the latest events in the world. Virtually all the major newspapers in the world have their own web pages. Information on the diversity of periodicals can be obtained, by visiting the MEDIA LINKS page (http:// www.mediainfo.com/emedia), which offers links to many editions. [8]

The method of project training is aimed at achieving the predicted results of students' self-study. For foreign language classes, the project, which is a specially organized by a teacher, is a complex of activities that is performed by students independently and ends with the design of a creative product. The project is valuable, because in the course of its implementation, students learn to acquire knowledge and experience in cognitive and educational activities independently. Project methodology characterized by high communication and directs students to express their own thoughts, feelings, to their active inclusion in the real activity, to acceptance of personal responsibility for education.

The main goals of introducing the method of projects into the educational process are: to show the ability of an individual student or a group of students to use their research experience from learning process; realize their interest in subject of research, and increase knowledge about it; to demonstrate level of foreign language proficiency; to rise to a higher level of education, development and social maturity.

Organizing work on a project is important to adhere to several conditions: a) the topic may be related to the country the language being studied and the country of residence; $b$ ) the problem is formulated so as to target students to attract facts from related fields of knowledge and various sources of information; c) all students should be involved in work, and offering each student task based on its level of language training; d) to activate students' activities, offer an interesting and actual problem. 
The project method combines verbal expressions and others illustrative techniques: drawings, collages, plans, maps, questionnaires tables, graphs and charts. Thus, the development of communicative skills are reliably supported by the variety of means that transmit different information. The method of projects is capable of transforming the lessons of a foreign language in a discussion and research club, in which interesting, important and relevant problems for students are solved [5].

The role of a teacher in preparing presentations of projects lies in control and counseling of students. Teacher can also provide vocabulary and adjust grammatical constructions if necessary. Avaluating the projects can be done by students by voting, or the teacher evaluates the student's projects independently, but it is necessary to indicate the weaknesses and strengths of each project.

Application of the latest information and communication technologies should be used in students' self-study in learning foreign language. The Internet is unlimited access to the big amount of linguistic and ethnographic material, detailed description of the newest technologies, innovations, the ability to constantly raise the level of language training.

Communicating students online with foreigners changes their attitude to a foreign language, which turns from a subject into a real means of communication and becomes a powerful motivational factor for learning a foreign language.

The purpose of students' self-study with computer systems may be: the ability to independently pick up the material for the defined topic; learning the theoretical material; the ability to solve practical tasks in specialty and developing the skills of argumentation and writing essay on the proposed or self-chosen theme.

Today there are many computer programs for studying, developing and improving students' knowledge, skills and abilities:

- electronic dictionaries (Lingvo, Webster's Dictionary, Longman Dictionary, Macmillan English Dictinary and others);

- electronic translators for large texts (Prompt, Magic Goody and others);

- programs for learning a foreign language;

- foreign language testing software.

Use of video materials is an important element of students' self-study at mastering a foreign language. The effectiveness of video materials for communicative language teaching is obvious. From all available means video provides the most accurate display of the language in use, because it is used by specific speakers, is closely related to a certain language situation, and its communicative purpose is amplified by a number of visual encoded non-verbal means (poses, facial expressions, gestures) [7].

The selected video must match the topics studied by the program. Preparatory exercises should be done to predict the content of the film, learn vocabulary and activate background knowledge, a series of questions and tasks for verifying the understanding of video material, as well as the final set of exercises for discussion and creative writing tasks.

Conclusions. Correct organization of students' self-study while learning a foreign language based on the use of active methods and innovative technologies with motivation to perform specific tasks and exercises, contributes to the successful and effective study of a foreign language, as well as develops the skills of self-education and the desire to professional self-improvement, and develops the ability to make own decisions. Application of the latest information and communication technologies deserves extensive use in students' self-study. Computer technologies and the Internet provide an opportunity for an integrated developing of speaking, reading, writing and listening skills. They will make it easier to understand the culture of country being studied and encourage interest in learning a foreign language.

Prospects for future research directions are to study the innovative technologies of teaching a foreign language for professional direction.

\section{References:}

1. Гинзбург Р. С., Лебединская Е. О самостоятельной работе учителей английского языка (работа над текстом). Иностранные языки в школе. 2012. № 8. С. 94-97.

2. Демченко О. Дидактична система організації самостійної роботи студентів. Рідна школа. 2006. № 5. С. 68-70.

3. Дичківська I. М. Інноваційні педагогічні технології. Київ: Академвидав, 2004. 351 с.

4. Корнєва 3. М. Самостійна робота як провідна форма організації навчальної діяльності з оволодіння іноземною мовою професійного спрямування у немовному вищому закладі освіти. URL: // http://ela.kpi.ua/handle/123456789/8483.

5. Кохан О. М., Михайлова Н. О. Організація самостійної роботи студентів під час навчання іноземної мови. URL: http://dspace. nuft.edu.ua/jspui/bitstream/123456789/12538/1/The\%20self.pdf.

6. Нечаев В. Я. Социология образования: Курс лекций. Москва: Центр социологии образования, 1998. 190 с.

7. Олійник Л. Й. Інноваційні технології викладання іноземних мов. URL: // http://www.rusnauka.com/Page_ru.htm.

8. Полат Е. С. Интернет на уроках иностранного язика. Иностранные языки в школе. 2001. № 2. С. 58-62.

9. Ягельська Н. В. Методика організації самостійної роботи студентів з англійської мови з використанням професійного мовного портфеля: автореф. дис. ... канд. пед. Наук: 13.00.02 ; Київ.нац. лінгвіст. ун-т. Київ, 2005. 23 с. 